\title{
Rámcové vzdělávací programy a paradigma světových náboženství ${ }^{1}$
}

\author{
Jakub Havlíček \\ Univerzita Palackého v Olomouci, Filozofická fakulta
}

\begin{abstract}
Abstrakt: Studie se zabývá paradigmatem světových náboženství ve výuce o náboženstvích v českém vzdělávání z hlediska religionistiky. Shrnuje kritiku paradigmatu světových náboženství v religionistice. Formování paradigmatu světových náboženství v 19. století je založeno na teologických východiscích, je spjato s kolonialismem, není objektivně vymezitelné, je vysoce abstraktní a ahistorické, vede k esencialistickému a normativnímu chápání náboženství. Analýza obsahu rámcových vzdělávacích programů ukazuje, že pojetí náboženské tematiky je založeno na tomto paradigmatu. $V$ rámcovém programu pro základní školy se uvádí křest’anství, judaismus a islám, s důrazem na první z tradic. Rámcový program pro gymnázia spojuje náboženské tradice s koncepcí civilizačních okruhů. Esencialisticky a vysoce abstraktně pojatá světová náboženství jsou základem civilizačních celků, podobně jako v kritizované koncepci světových civilizací Samuela P. Huntingtona. Uplatnění paradigmatu světových náboženství v kurikulárních dokumentech umožňuje formování paušalizujících, stereotypních představ o náboženských tradicích a identitách.
\end{abstract}

Kličová slova: kulturální kritika, kurikulum, náboženství, paradigma, rámcové vzdělávací programy, religionistika, společenskovědní předměty, stereotypy, světová náboženství, taxonomie

\section{Framework Education Programmes and the World Religions Paradigm}

Abstract: The paper deals with the world religions paradigm (WRP) in education on religions in the Czech education. The paper summarizes the criticism of WRP in the study of religions. The WRP formed in the 19th century under strong influence of Christian theology and colonialism, there are no objective criteria for its defining, it is highly abstract, ahistorical and it leads to essentialism and normative understanding of religions. The analysis of framework education programmes reveals that the WRP is applied in this curricular documents. The framework programme for basic education covers Christianity, Judaism and Islam, while Christianity has a privileged position. Framework programme for secondary education connects religions with the concept of civilization circles. World religions, understood in essentialistic and highly abstract terms, represent a basis for culture circles. This concept corresponds with the model of world civilizations by S. P. Huntington. In this perspective, world civilizations are based on religious traditions of WRP. European civilization is founded on Christianity, other religions are represented as aliens. The WRP in framework programmes enables formation of stereotypes on religious traditions and identities.

Keywords: cultural criticism, curriculum, framework educational programs, humanities, religions, stereotypes, study of religions, taxonomy, world religions paradigm

1 Zpracování a vydání publikace bylo umožněno díky finanční podpoře Filozofické fakulty Univerzity Palackého v Olomouci v roce 2018 z fondu pro podporu vědecké činnosti (grant FPVČ 2015/03 „Re-produkce vědění o náboženství a vzdělávací systém v moderní české společnosti“). 
Studie² se zabývá problematikou kategorizace a klasifikace náboženství prostřednictvím tzv. paradigmatu světových náboženství. Shrnuje výsledky debat k paradigmatu světových náboženství v současné religionistice s ohledem na kritiku tohoto paradigmatu. Jednotlivé body této kritiky poté uvádí do vztahu s obsahem rámcových vzdělávacích programů pro základní a gymnaziální vzdělávání. Rámcové vzdělávací programy se stávají předmětem analýzy především proto, že představují základní kurikulární dokumenty $v$ českém vzdělávání, a jsou tedy prvním logickým cílem badatelské práce. Zaměření na tematiku náboženství je dáno aktuálností této problematiky nejen $v$ sociálněvědním prostředí, ale i $v$ debatách probíhajících mimo oblast sociálních věd. ${ }^{3}$

Světová náboženství jsou kategorií, k niž se obvykle počítají křest’anství, judaismus, islám, hinduismus a buddhismus. Nejen kategorie světových náboženství, ale i označení pro jednotlivé tradice, které tuto kategorii naplňují, lze na první pohled bez větších potíží vymezit jak co do obsahu či nauky, tak pokud jde o praxi nebo geografické rozšíření. Budeme-li se však zabývat souvislostmi, v nichž se formuje pojetí světových náboženství a obsahové vymezení pojmu světových náboženství, $\mathrm{s}$ jednotlivými tradicemi, zjistíme, že se jedná o kategorie $v$ mnoha ohledech problematické a obtižně definovatelné. Při bližším kritickém pohledu na dějiny formování těchto kategorií i na kontexty, v nichž se využívají, se navíc ukazuje, že se nejedná o neutrální systematizaci. Paradigma světových náboženství mưže naopak snadno vést $\mathrm{k}$ formování stereotypů, zavádějících, či dokonce mylných představ o jevech, kterými je naplňováno.

Studie si klade za cíl odpovědět na následující rámcové otázky: Jaké jsou klíčové body kritiky paradigmatu světových náboženství v současném sociálněvědním bádání o náboženství, zejména v religionistice? Jak můžeme kritiku paradigmatu světových náboženství v religionistice spojit s problematikou výuky o náboženstvích? Jaké místo a souvislosti mají kategorie světových náboženství a náboženské tradice $k$ ní řazené v kurikulárních dokumentech v prostředí českého vzdělávání? V závěru se studie pokouší rovněž o formulaci návrhů, jak v tvorbě kurikula a ve výuce přistupovat k problematice náboženství v souladu s poznatky vyplývajícími z kritického př́stupu ke studiu náboženství v sociálních vědách.

Obecné zaměření studie na rozbor koncepční a obsahové stránky rámcových vzdělávacích programů navazuje na již publikované práce. Mezi nimi lze uvést např. studie Zdeňka Beneše (2005), Dominika Dvořáka (2007) či Jana Květiny (2016). Tyto přispěvky se zabývají mimo jiné problematikou zacházení s pojmy a koncepty v rám-

2 Děkuji redakci časopisu Orbis scholae a anonymním recenzentům za řadu podnětů a připomínek, které významně napomohly k vyjasnění a zpřehlednění konečné verze studie.

3 Následující text vzhledem $\mathrm{k}$ svému zaměření a nutně omezenému rozsahu představuje pouze první krok komplexní badatelské práce, která bude pokračovat rozborem dalších dokumentů, jako jsou např. školní vzdělávací programy a učebnice. O aktuálnosti tematiky, jíž se věnuje tato studie, svědčí kupř. monografie Z. Černé (2017) zaměřená na problematiku náboženství ve vzdělávání, zejména ve středoškolských učebnicích. Kniha byla publikována v době, kdy byla tato studie již dokončena a procházela recenzním řízením. 
cových programech. To ukazuje na důležitost epistemologických otázek, které je tře-

ba řešit v souvislosti s analýzou obsahové stránky kurikula (Dvořák, 2012, s. 66-68).

\section{Teoretická a metodologická východiska}

Metodologicky je studie založena na sekundární analýze publikací k problematice klasifikací náboženství, zvláště těch, které jsou zaměřeny na tzv. paradigma světových náboženství. Část práce, zaměřená na kurikulární dokumenty, vychází z kvantitativní analýzy obsahu a kvalitativní kritické diskurzivní analýzy rámcových vzdělávacích programů pro základní a gymnaziální vzdělávání.

Z teoretického hlediska vychází studie z perspektivy religionistiky jako sociálněvědní disciplíny zabývající se náboženstvími, ${ }^{4} \mathrm{~s}$ využitím přístupů dalších sociálněvědních disciplín, zejména sociologie (sociologie náboženství a sociologie vědění), antropologie náboženství a historie. Tematické zaměření na problematiku paradigmatu světových náboženství ve vzdělávání představuje propojení s pedagogikou.

Předmětem analýzy jsou dva základní kurikulární dokumenty: Rámcový vzdělávací program pro základní vzdělávání z roku 2016 a Rámcový vzdělávací program pro gymnázia z roku 2007. Design analýzy kombinuje kvantitativní a kvalitativní aspekty (Harwell, 2011; Vlčková, 2011).

Prvním krokem je obsahová, přesněji konceptuální frekvenční analýza (Dvořáková, 2010; Christie, 2007). V obou dokumentech je vyhledávána četnost výskytu základních pojmů či konceptů, které jsou spjaty s paradigmatem světových náboženství. Jde o pojmy náboženství a dále křest'anství, judaismus (židovství), islám, hinduismus a buddhismus. ${ }^{5}$ Východiskem je postup obsahové analýzy založené na deduktivně určených pojmech: ty jsou explicitně stanoveny na základě předem zvoleného teoretického rámce (Kuckartz, 2014, s. 55; Mayring, 2000), kterým je v případě této studie kritika paradigmatu světových náboženství v religionistice. Otevřené, důkladné objasnění teoretického rámce je při tomto postupu nezbytné, proto samotné analýze předchází shrnutí problematiky paradigmatu světových náboženství.

Základním cílem první části analýzy je zjistit, zda a v jaké míře se vůbec v obou kurikulárních dokumentech vyskytují pojmy, které jsou součástí paradigmatu světových náboženství. První krok analýzy rovněž umožní lokalizaci klíčových pojmů paradigmatu světových náboženství v textu obou rámcových vzdělávacích programů.

Lokalizace klíčových pojmů dovoluje druhý krok analýzy. Zde je východiskem kritická diskurzivní analýza definovaná jako analytické zkoumání vztahů kauzality a determinace mezi (a) diskurzivními praktikami, událostmi a texty; a (b) širšími sociálními a kulturními strukturami, vztahy a procesy (Fairclough, 1995, s. 132), a to

4 Religionistiku chápu jako vědní disciplínu zkoumající náboženství (Horyna, 1994) jakožto sociokulturní konstrukty (Havlíček, 2011), tedy jako zkoumání náboženství: „jak bylo a je lidmi vyjadřováno a popisováno, myšleno a žito, věřeno a provozováno." (Waardenburg, 1996, s. 11)

5 Z důvodu zpřesnění tematického vymezení textu ponechávám stranou problematiku nových náboženských hnutí, někdy označovaných hodnotově zatíženým, a tudíž z odborného hlediska nevhodným termínem sekty. 
54 na úrovních deskriptivní, interpretační a explanační (Fairclough, 1989). Jak ukazuje studie Jana Květiny (2016), je aplikace kritické diskurzivní analýzy v pedagogickém výzkumu kurikula plně využitelná právě v souvislosti s otázkou konceptualizace pojmů v kurikulárních dokumentech.

Cílem druhého analytického kroku je odpovědět na otázku, jak a v jakých souvislostech je $v$ rámcových vzdělávacích programech konceptualizována problematika náboženství a zejména $v$ jakých souvislostech se $v$ nich paradigma světových náboženství projevuje při konceptualizaci náboženství. Soustředím se právě na způsob, jakým se paradigma světových náboženství objevuje v obou dokumentech, a na epistemický kontext pojmů, které v obou kurikulárních dokumentech provázejí konceptualizaci náboženství v souvislosti s paradigmatem světových náboženství. Uvedený analytický postup je provázen nezbytnou metodickou abstrakcí a redukcí (srov. Burman \& Parker, 1993, s. 162), jejiž výchozí předpoklady je nutné podrobně popsat: zaměřme se proto nejprve na shrnutí kritiky paradigmatu světových náboženství v religionistice.

\section{Paradigma světových náboženství a jeho kritika}

Paradigma světových náboženství je klasifikačním systémem, jehož pomocí lze identifikovat a třídit náboženství v globální i lokální perspektivě jak v synchronní, tak $\checkmark$ diachronní rovině. Na první pohled se zdá, že jde o běžný taxonomický systém využitelný nejen ve vědeckém, ale i (patrně zejména díky své zdánlivé jednoduchosti) v mimovědeckém prostředí. Jako takový se zdá vyhovujícím prostředkem klasifikace jevů spojených s náboženstvími i ve výuce o náboženstvích. Na druhé straně však lze $v$ procesu formování paradigmatu světových náboženství i v jeho uplatňování identifikovat řadu problémů.

\subsection{Paradigma světových náboženství v religionistice}

Do kategorie světových náboženství se dnes obvykle zahrnuje pětice náboženských tradic: křest’anství, judaismus, islám, hinduismus a buddhismus (Cotter \& Robertson, 2016, s. 2). Toto klasifikační schéma je označováno jako paradigma světových náboženství, v anglicky psané odborné literatuře výrazem world religions paradigm nebo zkratkou WRP (Bell, 2006; Cotter \& Robertson, 2016; Cox, 2007; Owen, 2011; Tomalin, 2013).

Kategorie světových náboženství má $v$ dějinách bádání o náboženstvích více než stoletou historii. S pojmem světová náboženství se lze běžně setkat v publicistice, $\checkmark$ učebních materiálech i ve vědeckých publikacích. Není možné podat zde vyčerpávající přehled formování, užívání a vymezování kategorie světových náboženství v odborné literatuře i mimo vědecký diskurz, ${ }^{6}$ je však třeba se alespoň rámcově se-

6 Dějinám ustavování pojmu se podrobně věnuje Tomoko Masuzawa (2005) - viz dále v tomto textu. 
známit s tím, jak a v jakých souvislostech byla a je kategorie světových náboženství užívána a vymezována.

Jedním z často uváděných raných příkladů obsahového vymezení této kategorie (Hartney \& Tower, 2016, s. 62-63; Masuzawa, 2005, s. 109-114; Robinson, 2006, s. 24; Smith, 1998, s. 279) je to, které podává holandský teolog a historik náboženství Cornelis Petrus Tiele (1886). Tiele rozlišuje přírodní a etická náboženství, přičemž tuto druhou skupinu dále dělí na nomistická či nomotetická náboženství, založená na zákonu či svatém písmu, a univerzální či světová náboženství (tamtéž, s. 366-368). K této skupině Tiele řadí výslovně tři tradice: buddhismus, křest’anství a „mohamedánství“, tedy islám (tamtéž, s. 368).

Debaty kolem použitelnosti a vymezení pojmu shrnuje Tiele tak, že termín světová náboženství lze využít k praktickému odlišení uvedených tří tradic od jiných náboženství, které, pokud se rozšírily mimo komunitu svých původních přívrženců, „učinily tak pouze v návaznosti na a ve spojení s nadřazenou civilizaci““ (Tiele, 1886, s. 368). Konstatuje, že zatímco konfuciánství, bráhmanismus, džinismus, mazdaismus, judaismus a další tradice jsou spjaty s jedním „národem“,7 po staletí stagnují, či dokonce mizí, zmíněné tři tradice naopak zahrnují miliony přívrženců všech možných „národů a ras“, což je podle něj dáno především povahou těchto tří tradic (tamtéž, s. 368-369).

Tiele nicméně konstatuje, že mezi třemi univerzalistickými tradicemi je nutno rozlišovat, nebot’ např. islám „není původní, není vyzrálým ovocem, nýbrž divokým výhonkem judaismu a křest’anství “ (Tiele, 1886, s. 369). Buddhismus zase nebyl podle Tieleho mínění schopen se prosadit jinde než tam, kde se potýkal s „náboženstvími stojícími na nevysokém stupni vývoje“ (tamtéž). Jako protestantský teolog pochopitelně vyzdvihuje mezi světovými náboženstvími křest’anství, které se „nesouměřitelně řadí nad oba své soupeře“ (tamtéž).

Pozdější badatelé obsah kategorie světových náboženství rozšiřují a řadí k němu další konkrétní „druhy“. K obvykle citovaným příkladům (Masuzawa, 2005, s. 305-306; Molendijk, 2016, s. 176; Sun, 2013, s. 97) patři vymezení, které podává Max Weber, jedna ze zakládajících osobností sociologie náboženství (Weber, 1923/1998). Weber definuje tuto kategorii v úvodu k rozsáhlému dílu Hospodářská etika světových náboženství (Die Wirtschaftsethik der Weltreligionen) - tento úvod Weber napsal v roce 1913 a poprvé uveřejnil o dva roky později (Weber, 1915/1946, s. 267). Píše zde:

Pod pojmem „světová náboženstvi““ zde budeme rozumět - bez jakéhokoli hodnocení - těch pět náboženských nebo nábožensky podmíněných systémů životních pravidel, které kolem sebe vědomě shromáždily velké množství stoupencủ: konfuciánskou,

7 C. P. Tiele s ohledem na jazykový a dobový kontext svého pojednání označuje pojmem národ (nation) různé státní, etnické a jiné pospolitosti starověkého a středověkého světa. Napríklad konfuciánství a taoismus, které někteří autoři později přidávají do kategorie světových náboženství, označuje Tiele jako starověká národní náboženství (ancient national religion) Cínanů (Tiele, 1886, s. 363). 
hinduistickou, buddhistickou, křest’anskou, islámskou náboženskou etiku. K nim se připojuje jako šesté rozebírané náboženství židovství. (Weber, 1920/1989, s. 83-84) ${ }^{8}$

Německý protestantský teolog, historik a sociolog náboženství Ernst Troeltsch ve své přednášce na téma vztahu křest’anství a světových náboženství, napsané v roce 1923, řadí do skupiny světových náboženství kromě křest’anství, islámu a buddhismu ještě judaismus a zoroastrismus a přidává sem také konfuciánství (Troeltsch, 1923/1999, s. 17).

Proměny obsahu paradigmatu světových náboženství lze sledovat dále $v$ průběhu 20. století. Americký historik David Saville Muzzey na počátku čtyřicátých let 20. století uvádí mezi světovými náboženstvími pět tradic, které do této kategorie řadí i Troeltsch, ovšem bez konfuciánství (Muzzey, 1943, s. 39).

Skotský religionista Ninian Smart působící ve Spojených státech amerických jmenuje ve spojení s kategorií světových náboženství křest’anství, judaismus, islám, buddhismus, hinduismus a konfucianismus a dodává:

Taoismus v Číně, šintoismus v Japonsku, džinistické a sikhské náboženství v Indii, spolu s některými moderními odnožemi křest’anství na Západě, jako církev Svatých posledních dnů, jsou také důležité. Ale přestože některé z těchto věr, zvláště křest'anství, buddhismus a islám, stále mají stovky milionů přivrženců, soupeři s nimi o přizeň stoupenců nové síly. (Smart, 1969, s. 5)

Podobně jako kdysi před ním Cornelis Petrus Tiele, i Ninian Smart považuje za kritérium přislušnosti ke kategorii světových náboženství prvek moci či síly př́slušné tradice, kterou Smart spojuje s počtem následovníků.

Stručný přehled pojetí paradigmatu světových náboženství v 19. a 20. století jistě není vyčerpávající, lze jej však považovat za ilustraci toho, jak se v badatelské tradici $k$ této koncepci přistupuje. I $z$ tohoto nedlouhého přehledu je patrné přinejmenším to, že paradigma světových náboženství představuje kategorizační systém s nepř́liš jasně stanovenými hranicemi, což je také jeden z významných bodů, vǔči kterému směřuje jeho kritika.

\subsection{Hlavní body kritiky paradigmatu světových náboženství}

V posledních desetiletích se $v$ oblasti religionistiky objevuje kritika konceptů spojených s problematikou náboženství, teoretického ukotvení religionistiky a nakonec i religionistiky jako takové, jež se $v$ rámci této disciplíny objevuje ve spojení s kulturálním obratem a z něj vyrůstající kulturální kritikou (Lynch, 2012). ${ }^{9}$ Lze říci, že tato kritika v religionistice vychází především ze dvou základních zdrojů či předpokladů: prvním je s různou mírou radikality chápaná teze sociokulturního konstruktivismu

Za překlad děkuji Mgr. Ivě Mikulové, Ph.D.

9 Mezi autory, kteří kritizují užívání pojmu náboženství ve vědě a nakonec také religionistiku či vědecké studium náboženství, můžeme uvést Russella T. McCutcheona (1997), Timothyho Fitzgeralda (2000) či Daniela Dubuissona (2003) - viz také Havlíček (2013). 
(Havliček, 2013, s. 168-169). Druhým jednoduchým, avšak zásadním principem je, že bádání o náboženstvích je samo součástí sociokulturního kontextu, v němž se odehrává - tuto tezi je možné označit jako princip reflexivity. Religionistika je totiž založena na dobové epistémé, která „definuje podmínky možnosti každého vědění, at' už je to vědění vyjádřené v teorii, nebo tiše vtělené do praxe“ (Foucault, 2007, s. 133).

Mezi pojmy a kategorie, jejichž užívání je vystaveno kritice a jejichž konceptualizace se stává předmětem reflexivního, kritického přehodnocení, patří i paradigma světových náboženství. Hlavní body kritiky tohoto paradigmatu je možné shrnout takto: 10

Je teologické. Jeho formování lze klást do 19. století, kdy křest’anští teologové a misionáři vytvářejí toto paradigma jako prostředek k uchopení náboženské diverzity a zejména jako konceptualizační základ mezináboženského dialogu pojímajícího různé náboženské tradice jako alternativní cesty k Bohu (Fitzgerald, 1990, s. 104; Masuzawa, 2005, s. 72-104; Smith, 1998). Důsledkem je pojetí křest’anství jako vzoru (Bell, 2006), kdy se jako světová náboženství označují ta, která disponují nejen velkým počtem přívrženců, ale i dalšími atributy, jako jsou postava zakladatele, svatá písma, náboženské autority a příslušné obřady - jsou to pak právě tyto jevy, které obvykle tvoři jádro výkladu k přislušné náboženské tradici. Toto teologizující pojetí vede $k$ normativitě a esencialismu a k přehlížení řady dalších jevů spojených např. s tzv. žitou, obvykle nenormativní praxí konkrétních aktérů.

Formuje se $v$ souvislosti s kolonialismem a imperialismem 19. století. Kromě teologů a misionářů využivá paradigma světových náboženství i koloniální správa, které pomáhá systematizovat záplavu „domorodých“ idejí a praktik a orientovat se v ní. Paradigma světových náboženství dovoluje jednoduše klasifikovat náboženské ideje a praktiky a s nimi spojené identity v oblastech pod koloniální nadvládou zejména evropských mocností (Cotter \& Robertson, 2016; Chidester, 2014; Smith, 1998). Nejde však o jednostranný proces, nebot' na ideje a praxi kolonizátorů samožrejmě reagují i kolonizovaní. Příkladem světového náboženství, jehož pojetí je utvářeno ve specifických podmínkách vztahů kolonizovaných a kolonizátorů, může být hinduismus. Na formování kategorie hinduismu jako světového náboženství se starobylými kořeny např. mají významný podíl indičtí intelektuálové a představitelé směru tzv. neovédánty, která vzniká ve specifickém prostředí Brity kolonizované Indie (Fitzgerald, 1990;11 Fujda, 2010; Pennington, 2005).

Nelze podat žádná objektivní kritéria příslušnosti určitých tradic $k$ této kategorii. Viděli jsme již, že ke kategorii světových náboženství bývá obvykle řazena pětice tradic: křest'anství, judaismus, islám, hinduismus a buddhismus. Obsah kategorie však není nijak přesně vymezen a lze snadno nalézt řadu jiných pojetí (například

10 Podrobnější shrnutí klíčových bodů kritiky paradigmatu světových náboženství podávám ve stati World religions paradigm, legal system and education. The case of the Czech Republic (Havlíček, 2018).

11 Timothy Fitzgerald uplatňuje a dále rozvijí kritický pohled na religionistiku a také svá zjištění o formování konceptu hinduismem v monografii Ideologie religionistiky (Fitzgerald, 2000). 
58 Tiele, 1886, viz výše). Jako světové náboženství je však uváděno i konfuciánství (Sun, 2013) či zoroastrismus (Troeltsch, 1923/1999, s. 17). Naopak judaismus a hinduismus bývají vyjímány a zařazovány mezi etnická či národní náboženství (Stump, 2008, s. 13; Tomalin, 2013, s. 63). Kritériu světového rozšiření či univerzální, celosvětově šiřitelné nauky vyhovuje velké množství různých tradic, včetně těch, které jsou běžně řazeny např. mezi nová náboženská hnutí - dobrým př́kladem mưže být scientologie (Lužný, 1997, s. 86-89). Má-li být kritériem počet př́vržencủ, nelze objektivně stanovit žádnou hranici, kdy je určitá tradice zařaditelná mezi světová náboženství. Přiřazení ke světovým náboženstvím dodává určité tradici jistou legitimitu a i z toho je zjevné, že nejde ani zdaleka o neutrální, hodnotově nezabarvenou kategorii. Př́kladem náboženského směru, který se vědomě pokouší o sebeprezentaci v roli světového náboženství, může být tradice bahá'í (Lundberg, 2004).

Je ahistorické včetně koncepcí jednotlivých druhů náboženských tradic. Je-li kategorie světových náboženství objektivně nevymezitelná, nelze bez obtiźí stanovit ani obsah pojmů označujících jednotlivé druhy náboženských tradic, které se mezi světová náboženství obvykle řadí. $V$ religionistické odborné literatuře je častým př́kladem koncept hinduismu, kde v historické, ale ani v současné perspektivě není jasné, jaké jevy, ideje, praktiky atd. můžeme ještě označit jako hinduismus a co naopak vyloučit (Asad, 2001, s. 210-211; Fitzgerald, 1990, 2000, s. 134-155; Geaves, 2005; Oberoi, 1994; Pennington, 2005; Smith, 1962, s. 62-63). Prozkoumáme-li obsahovou náplň jakéhokoli pojmu označujícího určitou náboženskou tradici v historickém kontextu, ukazuje se, že její dnešní chápání prostě nelze jednoduše přenést do starších historických období. Proces, v němž se utvářejí koncepce náboženských tradic jako souborů věr a praktik s jasně popsatelnými dějinami, označuje americký religionista Wilfred Cantwell Smith jako proces reifikace či zvěcnění (Smith, 1962, s. 73). Tento proces historicky podmíněné konceptualizace je možné sledovat jak u pojmu náboženství, tak u jednotlivých náboženských tradic (tamtéž, s. 19-74; srov. Smith, 1998). Je však důležité připomenout, že dějinný proces reifikace se týká i západních ${ }^{12}$ tradic judaismu a křest’anství. Zkoumáme-li historické proměny konceptů tradic světových náboženství, můžeme se ptát, od jakého období lze už hovořit o existenci judaismu či buddhismu nebo jaké jevy je možné zahrnout pod kategorii té které náboženské tradice, např. co je ještě islámem a co už k němu nepatří.

12 Rozdělení na západní (evropské či euroamerické) a východní (asijské) náboženské tradice, byt’ se běžně a často nekriticky použivá i v současném odborném prostředí (Leaf, 2014a, 2014b), je také diskutabilní. Již tím, že náboženské tradice Západu, k nimž bývají obvykle řazena tzv. abrahámovská náboženství judaismus, křest’anství a islám, mají z prostého geografického hlediska svůj původ v Asii, kde jsou rovněž významně rozšířena. 


\section{Paradigma světových náboženství v rámcových vzdělávacích programech}

Seznámili jsme se s několika ukázkami vymezování kategorie světových náboženství a také s kritikou tohoto paradigmatu. Vedle toho je však paradigma světových náboženství užíváno i mimo badatelské prostředí spojené bezprostředně s vědeckým zkoumáním náboženství. Setkáme se s ním rovněž v oblasti vzdělávání - výjimkou není ani vzdělávání v oblasti náboženství v České republice. Analýza kurikulárních dokumentů pro základní a gymnaziální vzdělávání ukazuje, že paradigma světových náboženství je součástí konceptualizace náboženství v těchto dokumentech. Zaměřím se proto na kontext klíčového pojmu náboženství v obou dokumentech a rovněž na kontext dalších pojmů, které jsou základními součástmi paradigmatu světových náboženství. Z nich oba kurikulární dokumenty uvádějí judaismus, křest’anství a islám. Další obvyklé členy paradigmatického systému pětice světových náboženství, totiž hinduismus a buddhismus, kurikulární dokumenty neuvádějí.

\subsection{Rámcový vzdělávací program pro základní vzdělávání}

Jde-li o základní vzdělávání, lze hned na úvod říci, že problematika náboženství je $v$ rámcových vzdělávacích programech zmíněna jen okrajově. Odkaz k pojmu náboženství se v dokumentu vyskytuje šestkrát (RVP ZV, 2016, s. 54, 77, 133-134). Z druhů paradigmatu světového náboženství uvádí rámcový program především křest’anství, v pěti případech (s. 53-54), ve třech případech islám ${ }^{13}$ (s. 54) a pouze jednou judaismus (s. 53).

Pokud jde o koncept náboženství, ve vzdělávacím obsahu oboru geografie pro 2. stupeň se v popisu učiva vyskytuje pojem „náboženské oblasti“, obsah tohoto pojmu však není podrobněji specifikován (s. 77), a není tedy jasné, zda tento pojem můžeme uvést do přímého vztahu s geografií světových náboženství. Výraznější zastoupení má pojem náboženství v pasáži věnované prưřezovému tématu Multikulturní výchova (s. 132-134). Text rámcového programu zmiňuje v obecné rovině problematiku náboženství spolu s rozvojem znalostí, schopností a dovedností spojených s poznáním specifik sociokulturně odlišných skupin, které se žáci mají naučit nejen tolerovat, ale i spolupracovat s nimi - náboženství je tu uvedeno vedle národnostních a etnických charakteristik (s. 133).

Druhy paradigmatu světových náboženství jsou uvedeny bez výjimky v rámci vzdělávací oblasti Člověk a společnost, v souvislosti s oborem dějepis pro 2 . stupeň, kde se upozorňuje na tři tradice: křest’anství, islám a judaismus. Křest'anství je zmíněno v souvislosti se starověkými dějinami a kontextem jeho vzniku (s. 53) a poté několikrát v rámci dějin středověku (s. 54). Mezi výstupy z učení ve spojení se středověkými dějinami v dějepise pro 2. stupeň se mimo jiné uvádí schopnost vymezit „vztah křest’anství ke kacířství a jiným věroukám“ (tamtéž). Význam této

13 K islámu v učebnicích využívaných v českém školství viz Čermáková a Topinka (2016). 
60 formulace je nejasný již v tom, že není zřejmé, co mají autoři na mysli pod pojmem „jiné věrouky“. Jestliže jde o různé křest'anské ideové proudy středověku, v čem mají být jiné ve vztahu ke křest'anství? Má-li jít o nekřest’anské tradice, není zřejmé, které to mají být. Jedná-li se o „vztah křest’anství ke kacířstvi“, mezi ideové proudy spojené s křest’anstvím historicky patřilo a dodnes také patří značné množství různých konkrétních idejí a praktik, které lze jako „kaciřské“ (heterodoxní) označit výlučně z pohledu určitého směru nebo denominace, která se naopak prezentuje jako ortodoxní. Hovoří-li se o ortodoxii a heterodoxii, vždy jde o relativní kategorie vázané na konkrétní sociokulturní okolnosti, které musejí být přesněji specifikovány. $\checkmark$ prípadě, že tomu tak není, objevuje se riziko vzniku manipulativní dichotomie, kdy se předpokládá existence jakéhosi „pravého“ křest’anství, mimo jakýkoli historický kontext, a kacířství či jiných věrouk, které k němu prostě nepatří. Formulaci rámcového programu můžeme tedy vidět v souvislosti s teologizujícím, normativním pojetím křest’anství, v souvislostech reifikovaného konceptu, který je součástí paradigmatu světových náboženství. ${ }^{14}$

Judaismus je také uveden $v$ souvislosti s výstupy vzdělávacího oboru dějepis pro 2. stupeň (s. 53), kde se zmiňuje v souvislosti se vznikem křest'anství.

$\checkmark$ souvislosti s dějepisem pro 2 . stupeň se vyskytuje pojem islám. Rámcový vzdělávací program jej připomíná opět mezi výstupy učení v oblasti středověkých dějin, a to ve spojení se schopností žáka porovnat „základní rysy západoevropské, byzantsko-slovanské a islámské kulturní oblasti“. Význam pojmu „islámská kulturní oblast“ lze vykládat ve vztahu k obsahu učiva - zde se uvádí „islám a islámské říše ovlivňující Evropu (Arabové, Turci)“ (s. 54).

Obsah výuky a výstupy z učení dějepisu pro 2 . stupeň je tedy podrobněji zaměřen na křest'anství, především pokud jde o politické a kulturní dějiny středověku (s. 54). Jednotlivé druhy paradigmatu světových náboženství jsou v rámcovém programu spjaty se starověkými a zvláště se středověkými evropskými dějinami a jsou chápány jako homogenní, reifikované entity, lokalizované v př́slušných „kulturních oblastech“. To lze chápat jako důsledek uplatnění paradigmatu světových náboženství, které vystupuje ještě výrazněji v rámcovém programu pro gymnázia.

\subsection{Rámcový vzdělávací program pro gymnázia}

Rámcový vzdělávací program pro gymnázia z roku 2007 věnuje pojmu náboženství více pozornosti a uvádí jej jedenadvacetkrát (RVP G, 2007, s. 35, 42-44, 55, 72-75). $Z$ jednotlivých druhů paradigmatu světových náboženství je opět nejčastěji uvedeno křest’anství, pětkrát (s. 43-44, 72). Judaismus, resp. židovství či v náboženském slova smyslu židovská kultura, se vyskytuje ve třech případech $(s .43,46)$ a stejný počet výskytů patří pojmu islám (s. 44,46$)$.

14 Religionista a historik David Zbíral ve své monografii Největší hereze: Dualismus, učenecká vyprávění o katarství a budování křest'anské Evropy ukazuje, že v historiografických pracích lze snadno nalézt př́pady, kdy autoři nekriticky přejímají diskurz křest’anských autorit (Zbíral, 2007, s. 99-104). 
Zaměřme se nejprve na pojem náboženství. V oddílu společenskovědního základu Úvod do filozofie a religionistiky (s. 42) se mezi očekávanými výstupy jmenuje schopnost žáka rozlišit „významné náboženské systémy“ (tamtéž). Jde-li o systémy či tradice související s paradigmatem světových náboženství, to zde rámcový program neuvádí, byt' další obsah kurikulárního dokumentu tuto souvislost dovoluje konstatovat. Náboženství se připomíná také mezi sociokulturními charakteristikami v průřezovém tématu Multikulturní výchova (s. 73-75). Hovoří se zde o odlišných náboženských př́islušnostech a rovněž o předcházení či odstraňování nesnášenlivosti, diskriminace a předsudků spojených s náboženstvím (s. 74). Problematika náboženství je zmíněna i v rámci prưřezového tématu Výchova $k$ myšlení v evropských a globálních souvislostech. Mezi tematickými okruhy průřezového tématu je uvedeno téma:

Kulturní okruhy ve světě i v Evropě: etnická, jazyková a náboženská rozmanitost, civilizační okruhy, jejich specifikace, rozdíly a možnosti spolupráce; prolínání světových kultur, etnické, náboženské a kulturní konflikty jako důsledek globalizace. (s. 72)

Problematika náboženství se tu objevuje v perspektivě, kterou můžeme označit jako huntingtonovskou ideologii, ${ }^{15}$ jak je formulována v souvislosti s nábožensky definovanými civilizačními okruhy Samuelem P. Huntingtonem v jeho Střetu civilizací (Huntington, 2001). Konceptualizační slovník této ideologie je založen na antropogeografickém uvažování rakousko-německé či tzv. vídeňské difuzionistické školy, v jejímž prostředí se na konci 19. století objevuje teorie kulturních okruhů a která ve svých souvislostech navazuje na romantické představy o Volksgeist či duchu národů (Barnard, 2004, s. 50-51; Stocking, 1996, s. 3-8). Představitele klasického německého difuzionismu Lea Frobenia se Huntington (2001, s. 76) výslovně dovolává. $\checkmark$ této vysoce abstraktní typologické konstrukci, v základu stojící na elementární dichotomii my versus oni, ${ }^{16}$ lze podat více méně jednoduché až heslovité specifikace toho, co se označuje jako civilizační či kulturní okruhy. Vycházíme-li z této silně zjednodušující perspektivy, dovoluje to hovořit i o „možnostech spolupráce“ mezi těmito vysoce abstraktními entitami. Tato ideologie je zároveň ahistorická, nebot' prostě počítá s dějinnou existencí civilizačních okruhů a odhliží od historických okolností, konkrétních sociokulturních kontextů, v nichž se formují pojmy, které mají tyto civilizace utvářet.

Zmiňuje-li rámcový vzdělávací program rozmanitost, má tato různorodost s ohledem na kontext, $v$ němž se o ní hovoří, právě podobu světa s několika jednoduše

15 Jak ve své krátké kritice Huntingtonova Střetu civilizací výstižně uvádí Edward W. Said: „Huntington je ideologem, který chce učinit ,civilizace' a ,identity“ něčím, čím nejsou: uzavřenými, zapečetěnými entitami, které byly zbaveny nesčetných proudů a protiproudů, jež oživují lidské dějiny. “ (Said, 2001, s. 12)

16 Dichotomii my a oni Huntington komentuje v pasáži nadepsané Dva světy: my a oni (Huntington, 2001, s. 20-22). Byt' se z obsahu této pasáže zdá, že autor považuje tento obraz světa za príliš zjednodušující, svým přistupem nakonec vytváří stejně pojatý světonázor - pouze místo dvou zavádí devět kategorií, které však $v$ důsledku vedou k totožnému vnímání světa $v$ zjednodušujících protikladných vztazích. 
62 popsatelnými civilizačními okruhy, jimž v této perspektivě odpovídají jednotlivá světová náboženství. To, že se v případě významných náboženských systémů jedná o ta, která jsou zmiňována jako součást paradigmatu světových náboženství, potvrdí další obsah kurikulárního dokumentu a kontext výskytu jednotlivých druhů paradigmatu světových náboženství.

Křest’anství je v rámcovém vzdělávacím programu pro gymnázia uvedeno pětkrát, jednou je připomenut pojem christianizace, a to ve spojení se středověkými dějinami (s. 44). Z kontextu, v němž se pojem křest’anství vyskytuje, je zřejmé, že právě tato tradice je autory programu vnímána jako evropské náboženství, resp. tradice vlastní evropské kultuře či evropské civilizaci, což zcela odpovídá huntingtonovské ideologii civilizačních okruhů.

V očekávaných výstupech učení v oboru dějepis je křest'anství zmíněno v souvislosti se starověkými dějinami. Spolu s antikou a „vybranými“ starověkými společenstvími je zde křest'anství uvedeno jako jeden ze „základních fenoménů, z nichž vyrůstá evropská civilizace“ (s. 43). V těchto souvislostech je konstatována i návaznost křest’anství na judaismus, který je ovšem představen jako neevropský kulturní systém (tamtéž). U středověkých dějin je křest’anství zmíněno hned dvakrát. Je charakterizováno jako kulturní a společenské pojítko, avšak poukazuje se i na jeho vnitřní nejednotu (s. 44). Je to výjimečný př́ípad, kdy rámcový program explicitně upozorňuje na pluralitu uvnitř některé z náboženských tradic řazených $\mathrm{k}$ paradigmatu světových náboženství, avšak děje se tak v souvislosti s tematikou husitství, kde se tomuto pohledu prakticky nelze vyhnout.

Naposledy je křest'anství uvedeno $v$ rámci prưřezového tématu Výchova $k$ myšlení $\checkmark$ evropských a globálních souvislostech. $V$ rámci tematického okruhu nazvaného Žijeme v Evropě je křest'anství zahrnuto mezi „evropské kulturní kořeny a hodnoty“ (s. 72) a postaveno hned na první místo mezi těmito hodnotami. Tyto hodnoty tvoří „křest’anství, demokracie, právo, umění, věda, hospodářstvi““ (tamtéž). V souladu s huntingtonovskou ideologií světových civilizací, jejichž prvořadým znakem je náboženství (Huntington, 2001, s. 40), stojí křest'anství mezi hodnotami evropské civilizace na prvním místě.

Vzdělávací obsah dějepisu zmiňuje třikrát tradici judaismu. Opět uvádí židovství v souvislosti se vznikem křest’anství ve starověku - tento případ zahrnuje hned dva výskyty výrazu „židovstvi“. Uvádí se zde schopnost žáka objasnit „židovství (vazbu mezi židovstvím a křest'anstvím) a další neevropské náboženské a kulturní systémy“ (s. 43). Spojení judaismu s „,neevropskými“ náboženskými systémy je pozoruhodné vzbuzuje otázku, kterou rámcový program ponechává bez jednoznačné odpovědi, totiž jaký je $v$ tomto pojetí vztah judaismu a evropského kulturního prostoru. $\mathrm{V}$ jakých souvislostech je toto téma pojato, ukazuje třetí zmínka o judaismu, která se $v$ dokumentu vyskytuje tentokrát v souvislosti se soudobými dějinami. Mezi očekávanými výstupy z učení je uvedena schopnost objasnit „význam islámské, židovské a některé další neevropské kultury v moderním světě“ (s. 46). Je zajímavé, že islámská a židovská kultura (at' již se pod těmito pojmy myslí cokoli) jsou uváděny ve spojení s „některou dalši“ (sic!) neevropskou kulturou, jako by kulturní jevy vy- 
cházející z islámu či judaismu nepatřily ke kulturním fenoménům, které jsou v dějinách nedílnou součástí evropského prostoru. Lze si klást otázku, jaký je vlastně význam této formulace - mají-li snad autoři na mysli původ judaismu a islámu mimo evropský geografický prostor, je to samozřejmě také případ křest’anství, jehož historický příběh je nedílnou součástí asijského geografického prostoru. Pojetí RVP G tedy představuje judaismus a islám jako tradice, které jsou evropskému kulturnímu prostoru jednoduše cizí. Na mapě, kterou vytváří huntingtonovská ideologie civilizačních okruhů a která koresponduje s paradigmatem světových náboženství, judaismus a islám do Evropy nespadají.

Islám je v rámcovém programu uveden také třikrát, opět v souvislosti s obsahem výuky a s výstupy dějepisu. Ve spojení s dějinami středověku se očekává schopnost vymezit „specifika islámské oblasti“ (s. 44) s tím, že tato oblast je zřejmě určena níže zmíněným obsahem učiva „islám a arabská říše, mongolská a turecká expanze“ (tamtéž). Přesto není zřejmé, co patří mezi uvedená specifika takto široce vymezené tematické kategorie. Vyplývá-li z formulace obsahu učiva spojení mongolské expanze s islámem, je to přinejmenším zavádějící, nebot’ mongolská říše a státní útvary na ni navazující představovaly z hlediska náboženství nesmírně bohatý konglomerát, spjatý mimo jiné s buddhistickými a křest’anskými tradicemi a vírami a praktikami řazenými k tzv. šamanismu ${ }^{17}$ (Lane, 2006, s. 181-204). Potřetí je islám vzpomenut spolu s judaismem v uvedeném případě očekávaných výstupů z učení v oblasti soudobých dějin, v souvislosti s neevropskými náboženskými a kulturními systémy.

V rámcových vzdělávacích programech neplní paradigma světových náboženství úlohu neutrálního kategorizačního nástroje. Naopak, je součástí ideologického, normativního světonázoru, který je založen na huntingtonovské ideologii civilizačních okruhů. Dovoluje stanovit, které kulturní prvky jsou tzv. cizí (islám, judaismus) a které naopak tzv. naše (křest’anství).

\section{Závěr}

Kategorizace světových náboženství plní roli paradigmatu - je normativním světonázorem, který umožňuje uchopit komplexní realitu světa kolem nás. Je-li však obsah paradigmatu světových náboženství vystaven kritickému přezkoumání, ukazuje se, že sestává z obtížně vymezitelných pojmů, jejichž hodnotová neutralita a vědecká platnost jsou přinejmenším zpochybnitelné. Nelze stanovit žádná objektivní kritéria, která by obstála ve světle kritické sociální vědy a nebyla založena na teologizujícím uvažování o ortodoxii a heterodoxii.

Můžeme se zároveň ptát také na to, jak se formují koncepce jednotlivých druhů náboženských tradic, kterými je toto paradigma naplňováno. Proces reifikace, který ústí v naše dnešní chápání jednotlivých kategorií paradigmatu světových náboženství jako svébytných, jasně vymezených entit či institucí, se může stát předmětem kritic-

17 Z hlediska religionistiky představuje pojem šamanismu rovněž badatelský konstrukt, který lze podrobit kritickému přezkoumání (Alberts, 2016). 
64 kého rozboru u všech druhů kategorie světových náboženství, samozřejmě nevyjímaje křest’anství, které je obvykle chápáno jako vzorový příklad světového náboženství.

Lze sledovat řadu príkladů vědeckých prací od 19. století až do současnosti, $\checkmark$ nichž je paradigma světových náboženství použito $k$ utř́idění jevư spojených s náboženstvími. Paradigmatická role systému světových náboženství je dobře patrná na tezích Samuela P. Huntingtona, jehož geograficky přesně lokalizované civilizační okruhy vycházejí právě z tohoto systému. Přestože bylo vystaveno kritice, je paradigma světových náboženství používáno $v$ souvislosti s religionistikou, politologií či ve výchově a vzdělávání. Místo deklarované plurality se tak pouze upevňuje stereotypní uvažování o daných, v podstatě ahistorických, neměnných sociokulturních identitách, které jsou jednoznačně geograficky lokalizovány a charakterizovány svými specifiky. ${ }^{18}$ Jak ukazují české rámcové vzdělávací programy, je to mimo jiné právě tato schopnost, která se má stát u žáků výstupem z učení v souvislosti s problematikou náboženství: totiž schopnost definovat specifika odlišných sociokulturních identit $\mathrm{s}$ jejich náboženstvími $v$ souvislosti $\mathrm{s}$ utvářením vědomí specifik vlastních evropské kultuře (srov. Květina, 2016, s. 321-323) a v drtivé miře spojovaných s křest’anstvím. Na jedné straně rámcové vzdělávací programy usilují o rozvoj tolerance k sociokulturním rozdílủm a předcházení stereotypnímu, předsudečnému uvažování, jak o tom svědčí např. formulace prưřezového tématu Multikulturní výchovy v obou analyzovaných rámcových programech. Na druhé straně však využitím paradigmatu světových náboženství kurikulární dokumenty upevňují ideu geograficky vymezených, homogenních náboženských identit s jasně vymezitelnými specifiky, kde pro poznání vnitřní různorodosti a mnohotvárnosti nezůstává mnoho prostoru.

S ohledem na jeho obsah a souvislosti jeho formování je vyloučeno, aby bylo paradigma světových náboženství pouze neutrálním kategorizačním nástrojem. V českém vzdělávání roli neutrálního klasifikačního systému neplní, ale, jak o tom svědčí analytická sonda do obsahu rámcových vzdělávacích programů, je naopak základem k formování světonázoru, v jehož základu stojí etnocentrická ${ }^{19}$ dichotomie „my“ versus „oni“. Islám a judaismus jsou z evropského civilizačního prostoru vylučovány, nebot' narušují jednoduchou mapu světa založenou na huntingtonovské ideologii, kde je evropský prostor vyveden v barvě reprezentující křest’anství. To neznamená, že by fenomény řazené do kategorie křest'anství nehrály $v$ dějinách Evropy zásadní roli. Perspektiva paradigmatu světových náboženství však vede spolu s formováním stereotypně vnímaných představ o sociokulturních identitách.

Autoři rámcových vzdělávacích plánů a vyučující předmětů, kde se žáci seznamují s tematikou náboženství, stojí před problémem, jak toto téma pojmout, uspořádat a vyložit. Tvorba kurikula s sebou tedy vždy nese nutnost redukce a abstrakce, tento proces však musí být autory kurikula prováděn reflektovaně (srov. Dvořák, 2007,

18 Viz Masuzawa (2005).

19 Jako etnocentrické lze v nejširším slova smyslu označit paradigmata či koncepce, které se prezentují jako hodnotově neutrální, ve skutečnosti však jsou založeny na určitých normách, idejích a hodnotách, které v důsledku vyzdvihují nad ty, jež jsou označovány jako odlišné (za upozornění na tyto souvislosti děkuji anonymnímu recenzentovi). 
s. 114). Měl by se také $v$ konkrétních tématech opírat o nejnovější poznatky relevantních vědeckých disciplín. Míra abstrakce a systematizace užitá v souvislosti s náboženstvími nesmí vést $\mathrm{k}$ formování stereotypních představ. Domnívám se, že zcela zrušit systematizační perspektivu tradic světových náboženství není možné. To, že se formovala v určitých historických, sociokulturních souvislostech, je velmi dobré si uvědomovat, ale samo o sobě to ještě není dostatečným důvodem $k$ úplnému opuštění celého systému. Navíc různě vykládané koncepce křest’anství, islámu, hinduismu či buddhismu jsou v řadě diskurzů dodnes běžně uživány. Rámcové vzdělávací programy, na ně navazující učební materiály a samozřejmě konkrétní obsahy výuky se však musí oprostit od jazyka dominance, hegemonizace, stereotypizace a homogenizace. Řešením může být větší důraz na heterogenitu či pluralitu v náboženských tradicích jak z hlediska norem, tak především v žité dimenzi, v dějinách i v současnosti. Proč by se žáci nemohli s touto pluralitou seznamovat prostřednictvím individuálních př́iběhů, s důrazem na perspektivu aktérư? Řešením tedy není přestat ve výuce mluvit o islámu či buddhismu. Řešení spočívá $v$ tom, pojmout a na konkrétních př́kladech ukázat náboženství v jejich rozmanitosti, nikoli v homogenních blocích huntingtonovské ideologie.

\section{Literatura}

Alberts, T. K. (2016). Shamanism, discourse, modernity. New York: Routledge.

Asad, T. (2001). Reading a modern classic. W. C. Smith's 'The Meaning and End of Religion'. History of Religions, 40(3), 205-222.

Barnard, A. (2004). History and theory in anthropology. Cambridge: Cambridge University Press.

Bell, C. (2006). Paradigms behind (and before) the modern concept of religion. History and Theory, 45(4), 27-46.

Beneš, Z. (2005). Výzva nebo destrukce? Česká kurikulární reforma a dějepis. Pedagogika, 55(1), 37-47.

Burman, E., \& Parker, I. (Eds.). (1993). Discourse analytic research: Repertoires and readings of texts in action. London: Routledge.

Cotter, Ch. R., \& Robertson, G. R. (Eds.). (2016). After world religions: Reconstructing religious studies. New York: Routledge.

Cox, J. L. (2007). From primitive to indigenous: The academic study of indigenous religions. Aldershot: Ashgate.

Čermáková, E., \& Topinka, D. (2016). Obraz islámu a muslimů v učebnicích pro základní školy. In D. Topinka (Ed.), Muslimové v Česku: Etablování muslimů na veřejnosti (s. 202-213). Brno: Barrister \& Principal.

Černá, Z. (2017). Reflexe náboženství ve vzdělávání s dưrazem na analýzu českých středoškolských materiálů. Pardubice: UP.

Dubuisson, D. (2003). The western construction of religion: Myths, knowledge, and ideology. Baltimore: Johns Hopkins University Press.

Dvořák, D. (2007). Pojmová analýza jednoho společenskovědního tématu v RVP. In T. Janík, P. Knecht, \& V. Najvarová (Eds.), Př́spěvky k tvorbě a výzkumu kurikula (s. 111-120). Brno: Paido.

Dvořák, D. (2012). Od osnov ke standardům: Proměny kurikulární teorie a praxe. Praha: PedF UK. 
66 Dvořáková, I. (2010). Obsahová analýza / formální obsahová analýza / kvantitativní obsahová analýza. AntropoWebzin, (2), 95-99. Dostupné z http://www.antropoweb.cz/media /document/antropowebzin-2-2010_1_.pdf

Fairclough, N. (1989). Language and power. London: Longman Group Limited.

Fairclough, N. (1995). Critical discourse analysis: The critical study of language. London: Longman Group Limited.

Fitzgerald, T. (1990). Hinduism and the "World Religion" fallacy. Religion, 20(2), 101-118.

Fitzgerald, T. (2000). The ideology of religious studies. New York: Oxford University Press.

Foucault, M. (2007). Slova a věci. Brno: Computer Press.

Fujda, M. (2010). Akulturace hinduismu a formování moderní religiozity: K sociálním dějinám českého okultismu 1891-1941. Praha: Malvern.

Geaves, R. (2005). The dangers of essentialism: South Asian communities in Britain and the 'world religions' approach to the study of religions. Contemporary South Asia, 14(1), 75-90.

Hartney, Ch., \& Tower, D. J. (2016). Religious categories and the construction of the indigenous. Boston: Brill.

Harwell, M. R. (2011). Research design in qualitative/quantitative/mixed methods. In C. F. Conrad \& R. C. Serlin (Eds.), The SAGE handbook for research in education: Pursuing ideas as the keystone of exemplary inquiry (s. 147-182). Thousand Oaks: SAGE Publications.

Havlíček, J. (2011). Cesty božstev: Otázky interpretace náboženství a nacionalismu v moderním Japonsku. Brno: MU.

Havlíček, J. (2013). Existuje v Japonsku náboženství? Kategorie náboženství a postmoderní kritika v sociálních vědách. Religio, 21(2), 163-188.

Havlíček, J. (2018). World religions paradigm, legal system and education: The case of the Czech Republic. Journal of Beliefs and Values, Studies in Religion and Education, 39(3), b. s. Dostupné z https://doi.org/10.1080/13617672.2018.1433920

Horyna, B. (1994). Úvod do religionistiky. Praha: ISE - Institut pro středoevropskou kulturu a politiku, Oikúmené.

Huntington, S. (2001). Střet civilizací: Boj kultur a proměna světového rádu. Praha: Rybka Publishers.

Chidester, D. (2014). Empire of religion: Imperialism and comparative religion. Chicago: University of Chicago Press.

Christie, Ch. (2007). Content analysis. In R. Baumeister \& K. Vohs (Eds.), Encyclopedia of social psychology (s. 176). Thousand Oaks: SAGE Publications.

Kuckartz, U. (2014). Qualitative text analysis: A quide to methods, practice and using software. Thousand Oaks: SAGE Publications.

Květina, J. (2016). Koncepce liberalismu a demokracie v edukačním procesu: Dekonstrukce neoliberální dominance v RVP. Pedagogika, 66(3), 312-329.

Lane, G. (2006). Daily life in the Mongol empire. London: Greenwood Press.

Leaf, M. J. (2014a). The anthropology of Eastern religions: Ideas, organizations, and constituencies. Lanham: Lexington Books.

Leaf, M. J. (2014b). The anthropology of Western religions: Ideas, organizations, and constituencies. Lanham: Lexington Books.

Lundberg, Z. (2004). Bahā'̄̄ and the holy land: Religiogenesis and Shoghi Effendi's The faith of Bahā'u'llāh: A world religion. In M. Sharon (Ed.), Studies in modern religions, religious movements and the Bābī-Bahā'ī faiths (s. 299-317). Leiden: Brill.

Lužný, D. (1997). Nová náboženská hnutí. Brno: MU.

Lynch, G. (2012). Living with two cultural turns: The case of the study of religion. In S. Roseneil \& S. Frosh (Eds.), Social research after the cultural turn (s. 73-92). New York: Palgrave Macmillan.

Masuzawa, T. (2005). The invention of world religions: Or, how European universalism was preserved in the language of pluralism. Chicago: University of Chicago Press.

Mayring, P. (2000). Qualitative content analysis. Forum Qualitative Sozialforschung / Forum: Qualitative Social Research, 1(2), b. s. Dostupné z http://nbn-resolving.de/urn:nbn :de:0114-fqs0002204 
McCutcheon, R. T. (1997). Manufacturing religion: The discourse on sui generis religion and the politics of nostalgia. New York: Oxford University Press.

Molendijk, A. L. (2016). Friedrich Max Müller and the sacred books of the East. Oxford: Oxford University Press.

Muzzey, D. S. (1943). Ethical religion: Its historical sources, its elements, its sufficiency, its future. New York: New Union Press.

Oberoi, H. (1994). The construction of religious boundaries: Culture, identity, and diversity in the Sikh tradition. Chicago: University of Chicago Press.

Owen, S. (2011). The world religions paradigm. Time for a change. Arts and Humanities in Higher Education, 10(3), 253-268.

Pennington, B. K. (2005). Was Hinduism invented? Britons, Indians, and the colonial construction of religion. Oxford: Oxford University Press.

Robinson, C. A. (2006). Interpretations of the Bhagavad-Gita and images of the Hindu tradition: The song of the lord. London: Routledge.

RVP G. (2007). Rámcový vzdělávací program pro gymnázia. Dostupné z http://www.msmt.cz /uploads/Vzdelavani/Skolska_reforma/RVP/RVP_gymnazia.pdf

RVP ZV. (2016). Rámcový vzdělávací program pro základní vzdělávání. Dostupné z http:// www.msmt.cz/file/37052/

Said, E. W. (2001). The clash of ignorance. Nation, 273(12), 11-14.

Smart, N. (1969). The religious experience of mankind. New York: Charles Scribner's Sons.

Smith, J. Z. (1998). Religion, religions, religious. In M. C. Taylor (Ed.), Critical terms for religious studies (s. 269-284). Chicago: University of Chicago Press.

Smith, W. C. (1962). The meaning and end of religion. New York: Mentor Books.

Stocking, G. W. (Ed.). (1996). Volksgeist as method and ethic: Essays on Boasian ethnography and the German anthropological tradition. Madison: University of Wisconsin Press.

Stump, R. W. (2008). The geography of religion: Time, place, and space. Lanham: Rowman \& Littlefield.

Sun, A. X. D. (2013). Confucianism as a world religion: Contested histories and contemporary realities. Princeton: Princeton University Press.

Tiele, C. P. (1886). Religions. In The encyclopaedia Britannica: Dictionary of arts, sciences, and general literature, ninth edition, volume XX (s. 358-371). Edinburgh: Adame and Charles Black.

Tomalin, E. (2013). Religions and development. New York: Routledge.

Troeltsch, E. (1923/1999). Christian thought: Its history and application. Lectures written for delivery in England during March 1923. Eugene: Wipf \& Stock Publishers.

Vlčková, K. (2011). Smíšený výzkum: Jedná se o nové a závažné téma? In T. Janík, P. Knecht, \& S. Šebestová (Eds.), Smíšený design v pedagogickém výzkumu: Sborník přispěvků z 19. výroční konference České asociace pedagogického výzkumu (s. 1-6). Brno: MU.

Waardenburg, J. (1996). Bohové zblizka: Systematický úvod do religionistiky. Brno: MU.

Weber, M. (1915/1946). The social psychology of the world religions. In H. H. Gerth \& C. Wright Mills (Eds.), From Max Weber: Essays in sociology (s. 267-301). New York: Oxford University Press.

Weber, M. (1920/1989). Die Wirtschaftsethik der Weltreligionen - Konfuzianismus und Taoismus: Schriften 1915-1920. Tübingen: J. C. B. Mohr (Paul Siebeck).

Weber, M. (1923/1998). Sociologie náboženství. Praha: Vyšehrad.

Zbíral, D. (2007). Největši hereze: Dualismus, učenecká vyprávění o katarství a budování křest'anské Evropy. Praha: Argo.

Mgr. Jakub Havlíček, Ph.D., katedra sociologie, andragogiky a kulturní antropologie Filozofická fakulta, Univerzita Palackého v Olomouci třída Svobody 26, 77900 Olomouc jakub.havlicek@upol.cz 